\title{
Study the hybrid PV/wind systems in Basrah city
}

\author{
Noor B Sakran and Salih I Najim \\ Department of Mechanical Engineering, University of Basra, College of Engineering, Iraq
}

Received 01 March 2019, Accepted 01 May 2019, Available online 02 May 2019, Vol.9, No.3 (May/June 2019)

\begin{abstract}
Renewable resources gained more attention in the last two decades due to persisting energy demand coupled with decrease in fossil fuel resources and its environmental effect to the earth. In this work, two cases of hybrid system will be studied. The first one dr. Jawad's home (Assistant professor in Electrical Engineering Department- University of Basrah). It is located in Al-Jazeera area that adjacent to the coast of the Shatt al - Arab that is located about $34 \mathrm{~km}$ south of the city center and its coordinates are $\left(30.12^{\circ} \mathrm{N}, 47.49^{\circ} \mathrm{E}\right)$ latitude and longitude respectively. He used a hybrid system consist of (PV panels-batteries and the wind power will be studied theoretically by suggests a $4.5 \mathrm{~kW}$ ) wind turbine system) to feeding home's load. The second case study is the laboratories of the Department of Electrical Engineering-University of Basrah.The Department located in Garmat Ali district (part of Al-Hartha area) that is located in the north east of Basrah city and its coordinates are $30.582^{\circ} \mathrm{N}$ latitude and $47.76^{\circ} \mathrm{E}$ longitude. The hybrid system that used in this department consists of (PV panels-batteries). Results showed from first case study that the total power saving when using hybrid system resources in the house that consume 33.24 MWh/year about 31.3\% by providing $10.4 \mathrm{MWh} /$ year. Through the study of the laboratories of the Department the results show that is possible to operate many electrical appliances at the same time depending on the hybrid system such as fans, lighting, and computers and it is noted that the air conditioners can be operated by using more and more solar cells and batteries.
\end{abstract}

Keywords: PV, Wind energy, Battery, Power

\section{Introduction}

The rapid depletion of fossil fuel resources worldwide has necessitated an urgent search for alternative energy sources to meet the present day demand. Alternative energy resources, such as solar and wind, which are clean, inexhaustible, and environmental friendly are potential resources for renewable energy (Ekren 0, 2009). Hybrid energy systems are combinations of two or more energy conversion devices (e.g., electricity generators or storage devices), or two or more fuels for the same device, that when integrated, overcome limitations that may be inherent in either. There are many researches that deals with hybrid system in Iraq and different countries such as Onar (2008) combined wind turbine (WT), photovoltaic (PV), fuel cell (FC) and ultracapacitor (UC) systems for grid-independent applications. The main contribution of this work was the hybridization of renewable energy sources with FC systems using longand short-term storage strategies with appropriate power controllers and control strategy to build an autonomous system (Onar OC, 2008). Reichling (2008)

*Corresponding author's ORCID ID: ORCID ID: 0000-0001-61107416; DOI: https://doi.org/10.14741/ijcet/v.9.3.1 modeled a hybrid wind-solar power plant in southwestern Minnesota for a 2-year period using hourly wind and solar irradiation data (Reichling JP, 2008). Yang (2008) recommended an optimal sizing method to optimize the configurations of a hybrid solar-wind system employing battery banks. Based on a genetic algorithm (GA), which has the ability to attain the global optimum with relative computational simplicity, one optimal sizing method was developed to calculate the optimum system configuration that could achieve the customers required loss of power supply probability (LPSP) with minimum annualized cost of system (ACS) (Yang H, 2008). Liu and Wang (2009) used Wind-PV system for China locations by taking load as road light of city, pumping system and made policy for the government for flourishing hybrid power utilization (Liu Li-qun, 2009). Dihrab and Sopian (2010) demonstrated hybrid system using wind and $\mathrm{PV}$ resource connected to the grid in three locations in Iraq. MATLAB solver software used for the simulation, by input the data of the three selected places for wind and solar PV. The study showed that the highest PV power in Basrah and then Mosul and Baghdad respectively while the output from wind turbine is highest in Basrah then Baghdad and Mosul respectively. The location of the power plant has great 
effect on plant performance (S. Dihrab, 2010). Ismael (2015) demonstrate stand - alone hybrid system consists of PV- wind and natural gas generator to supply a climate-friendly with zero pollution electricity to small town called Bald Ruz in Diyala- Iraq. HOMER software program used to do the optimization and find the best configuration, the PV system represents around $42 \%$ of power production small percentage for wind turbine that reaches to $6 \%$. He found that the cost of electricity was $0.998 \$ / \mathrm{kWh}$ for stand -alone hybrid system consist of wind-PV and diesel generator (A. Ismael, 2015). Abd al-Raheem, A. T. (2017) studied supply electricity for remote areas close to the marshes which are not connected to the national electricity grid. Researcher work aims were to reduce the dependence on electricity generation by diesel generators which are highly operational cost due to the cost of fuel as well as polluting the environment using different types of renewable power resources. The study is done in small village in Mayssan province, Abo Khsaf village. Two types of renewable power are takes (photovoltaic and wind), where the selected area has good rates of solar energy and wind reaches to $5.16 \mathrm{kWh} / \mathrm{m}^{2} /$ day and $5.6 \mathrm{~m} / \mathrm{s}$ respectively. HOMER software program is used to do the simulation of each system. He concluded that the hybrid power systems are flexible platforms that can provide cheaper electricity than systems using only one energy source in remote areas and low cost of electricity about $0.567 \$ / \mathrm{kWh}$ can get from PV-diesel system (Abd al-Raheem, 2017).

\section{Mathematical model}

\subsection{Photovoltaic module system}

The power generation from it depends on the specification of the cell. Output power at the reference condition can be determined by the equation (Abd alRaheem, 2017):

$P_{P M}(W)=V_{m p} \times I_{m p}$

Where

$P_{P M}$ : Maximum Power.

$V_{m p}$ : Voltage at peak power point.

$I_{m p}$ : Current at peak power point.

The efficiency of the solar cell can determine by:

$\eta=\frac{P_{P M}}{A \times G_{r}}$

Where

$A$ : Area of the solar panels $\left[\mathrm{m}^{2}\right]$.

Gr: Standard irradiation conduction which equal to $\left[1000 \mathrm{~W} / \mathrm{m}^{2}\right]$

\subsection{Wind power system module}

The power generated from the wind gives by the equation:

$\mathrm{Pw}=\frac{1}{2} \times \rho \times A \times V^{3}$

Betz limit means that no wind turbine can produced more than $0.59 \%$ of wind kinetic energy. Discovered by a German physicist called Albert Betz in 1919.This called (power coefficient) defined as $C_{P \text { Max }}$ whish equals to 0.59 (C. McGregor, 2010). The $\mathrm{Cp}$ value differed in each type of wind turbine and it is a function of wind speed that operating on it. So the power coefficient needs to take in equation (3) and the power equation is:

$P_{\text {avail }}=8 / 27 \times \mathrm{A} \times \rho \times V^{3} \times C_{P \operatorname{Max}}$

$\rho=$ The air density $\left[\mathrm{Kg} / \mathrm{m}^{3}\right]$

From equation (4) we see that the power exerted from the wind turbine depend on:

1- Wind speed (V).

2- Swept area (A).

Wind power increases due to increase the rotor blade length (r). The swept area calculated by using equation of circle area:

$A=\pi r^{2}$

\subsection{Battery bank mathematical model}

If the energy generated by the hybrid system (PV panel and wind turbine) is greater than the load, then the unused energy will be stored to be extracted at high demand time or high electricity price periods, this represent the the purpose of using battery bank.

Battery rating is commonly specified in terms of its Ampere-hour (Ah) or Watt-hour (Wh) capacity. The ampere-hour capacity of a battery is the quantity of discharge current available for a specified length of time at a certain temperature and discharge rate. High discharge current would result in reduction of the battery capacity and will decrease its life time.

At any hour the state of battery is related to the previous state of charge and to the energy production and consumption situation of the system during the time from $(\mathrm{t}-1)$ to $(\mathrm{t})$. During the charging process, when the total output of PV and wind generators is greater than the load demand, the available battery bank capacity at hour $t$ can be described by (Ai, B., Yang, 2003):

Ebat $=\operatorname{Ebat}(\mathrm{t}-1)(1-\sigma)+(\operatorname{Epv}(\mathrm{t})+\operatorname{Ewt}(\mathrm{t})$ $(\mathrm{El}(\mathrm{t}) / \eta$ inv $) *$ \bat 
On the other hand, when the load demand is greater than the available energy generated, the battery bank is in discharging state. Therefore, the available battery bank capacity at hour $t$ can be expressed as (Ai, B., Yang, 2003):

Ebat $=$ Ebat $(\mathrm{t}-1)(1-\sigma)-\left((\operatorname{El}(\mathrm{t}) / \eta \text { inv })^{*} \operatorname{Epv}(\mathrm{t})-\operatorname{Ewt}(\mathrm{t})\right)$

Where:

Ebat and Ebat (t-1) are the charge capacities of battery bank $(\mathrm{Wh})$ at the time $\mathrm{t}$ and $(\mathrm{t}-1)$ respectively, $\sigma$ : Is hourly self-discharge rate and equal 0.0014 , Ewt $(t)$ : is the energy from wind turbine during the time interval,

$\operatorname{Epv}(\mathrm{t})$ : is the energy from PV system during the time interval,

$\mathrm{El}(\mathrm{t})$ : is the load requirement during the time interval,

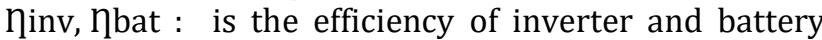
bank respectively as stated before. They equal 0.92 and 0.75 respectively.

\section{Description of the present case studies}

In order to get the maximum power from solar radiation in south of Iraq, we have chosen Basrah city. Basrah located in the southern of Iraq, situated at latitude of $30.46^{\circ}$ and longitude of $47.7^{\circ}$.

In this work, two cases of hybrid system will be studied. The first one dr. Jawad's home (Assistant professor in Electrical Engineering DepartmentUniversity of Basrah). It is located in Al-Jazeera area that adjacent to the coast of the Shatt al - Arab. Shatt Al-Arab area located about $34 \mathrm{~km}$ south of the city center and its coordinates are $\left(30.12^{\circ} \mathrm{N}, 47.49^{\circ} \mathrm{E}\right)$ latitude and longitude respectively as shown in Fig. (1) (https://ar.Wikipedia. Org./wiki/).

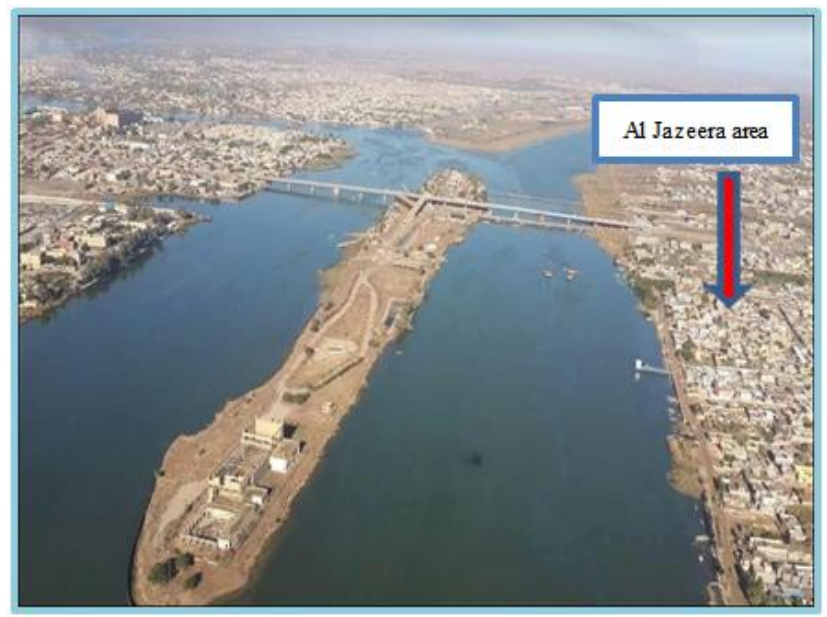

Fig $1 \mathrm{Al}$ Jazeera area in Basrah City (https://ar.Wikipedia. Org./wiki/)

The second case study is the laboratories of the Department of Electrical Engineering-University of Basrah.
The Department located in Garmat Ali district (part of Al-Hartha area). Al-Hartha located in the north east of Basrah city and its coordinates are $30.582^{\circ} \mathrm{N}$ latitude and $47.76^{\circ}$ E longitude as shown Fig. (2) (https://www.google.com/earth).

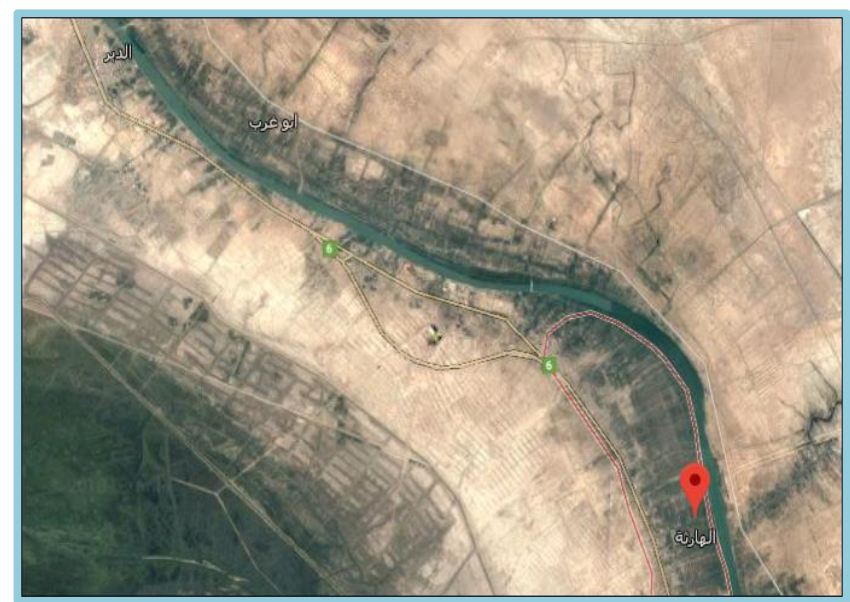

Fig.2 Map showing location of Al-Hartha area (https://www.google.com/earth)

\section{Selected Power systems}

In this study, Dr. Jawad' home will be taken as a case study of solar power in Basrah city. In this house the solar panels with capacity $(4.5 \mathrm{~kW})$, and module (PSP660250 - 4500W) is used to fed the home' load with electric energy.

While the wind power in the same city will be studied theoretically by suggests a $(4.5 \mathrm{~kW})$ wind turbine system module(FT-4500G).

\subsection{The Solar power system}

The first case study is dr.Jawad's home. He used (18) solar panels with the specifications mentioned in Table (1) and 4 batteries. These panels have been installed on the roof of the house recently 2017 see Fig. (3) and is currently working satisfactorily giving maximum power of $4.5 \mathrm{~kW}$.

In a solar system that has been used in this application, every 3_ panels are connected in series to get the string desired voltage $(\approx 90 \mathrm{~V})$. To fulfil the requirement of $4.5 \mathrm{~kW}$ system, 6 string have been connected in parallel in the combiner box. The combiner box output is connected to the charge controller. The last one output is connected to the four batteries bank from a side and the inverter's terminal from another side. The charge controller controls the charging and discharge process of the battery bank.

The inverter is programmed with a special program to show the readings on a screen manufactured 
manually by dr. Jawad and connected to the inverter, the readings appear in the form of a table contains voltage, current and other information. The readings of inverter were recorded for 2017.

The second case study is the laboratories in the department of Electrical Engineering - University of Basrah. It is located in Garmat Ali area (part of AlHartha region). The laboratories used (40) solar panels and battery bank consist of (8) batteries. This system giving a maximum power of $10 \mathrm{~kW}$. This power feeds (6) laboratories, each laboratory contains (9) ceiling fans, (32) indoor lights, (12) computers and other devices. The process of connecting solar cells and batteries is similar to the first case study. See Fig. (4).

Table 1 (PS- P660250) module technical specification

\begin{tabular}{|c|c|}
\hline Maximum power ( pmax) & $250 \mathrm{~W}(0 /+3 \%)$ \\
\hline Voltage at Pmax & $30.80 \mathrm{~V}$ \\
\hline Current at Pmax & $8.14 \mathrm{~A}$ \\
\hline Open -circuit Voltage (V oc) & $38.20 \mathrm{~V}$ \\
\hline Short-circuit current (I sc) & $9.00 \mathrm{~A}$ \\
\hline Maximum system voltage & $1000 \mathrm{~V}$ \\
\hline Dimensions & $1640 * 990 * 35 \mathrm{~mm}$ \\
\hline
\end{tabular}

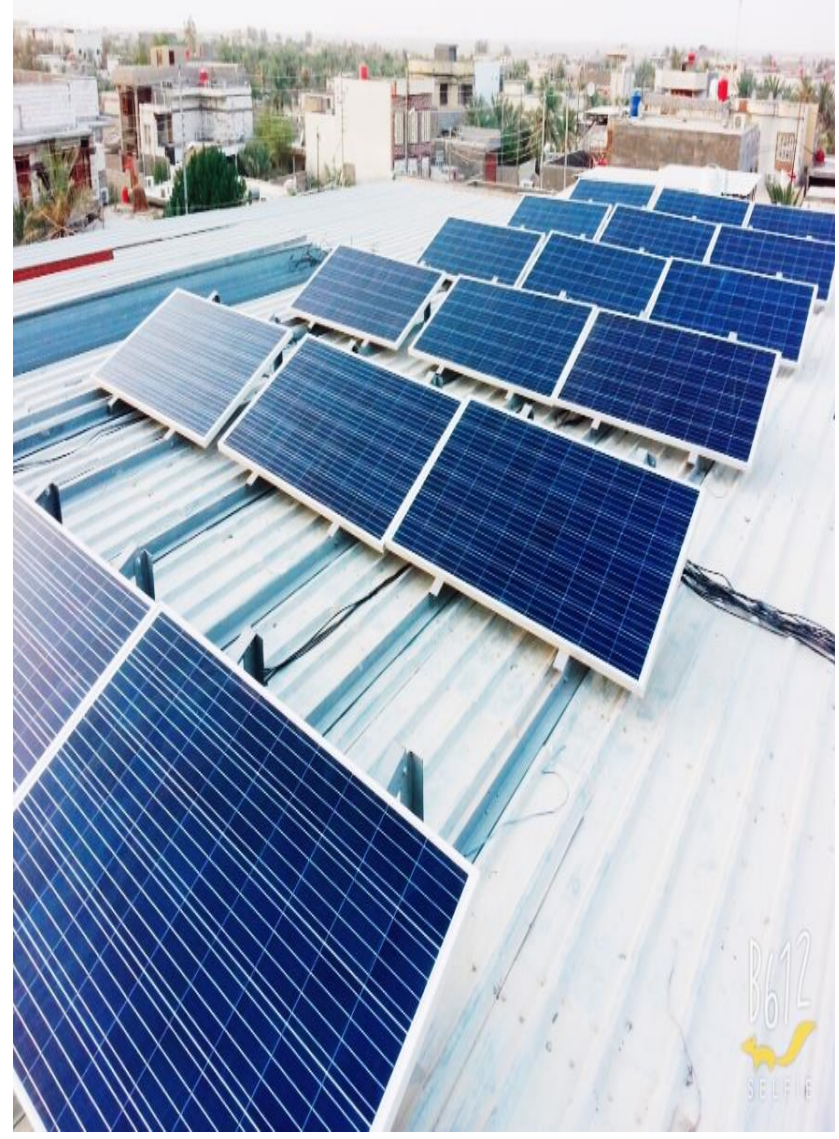

Fig.3 PV system Panels of Dr. Jawad's home

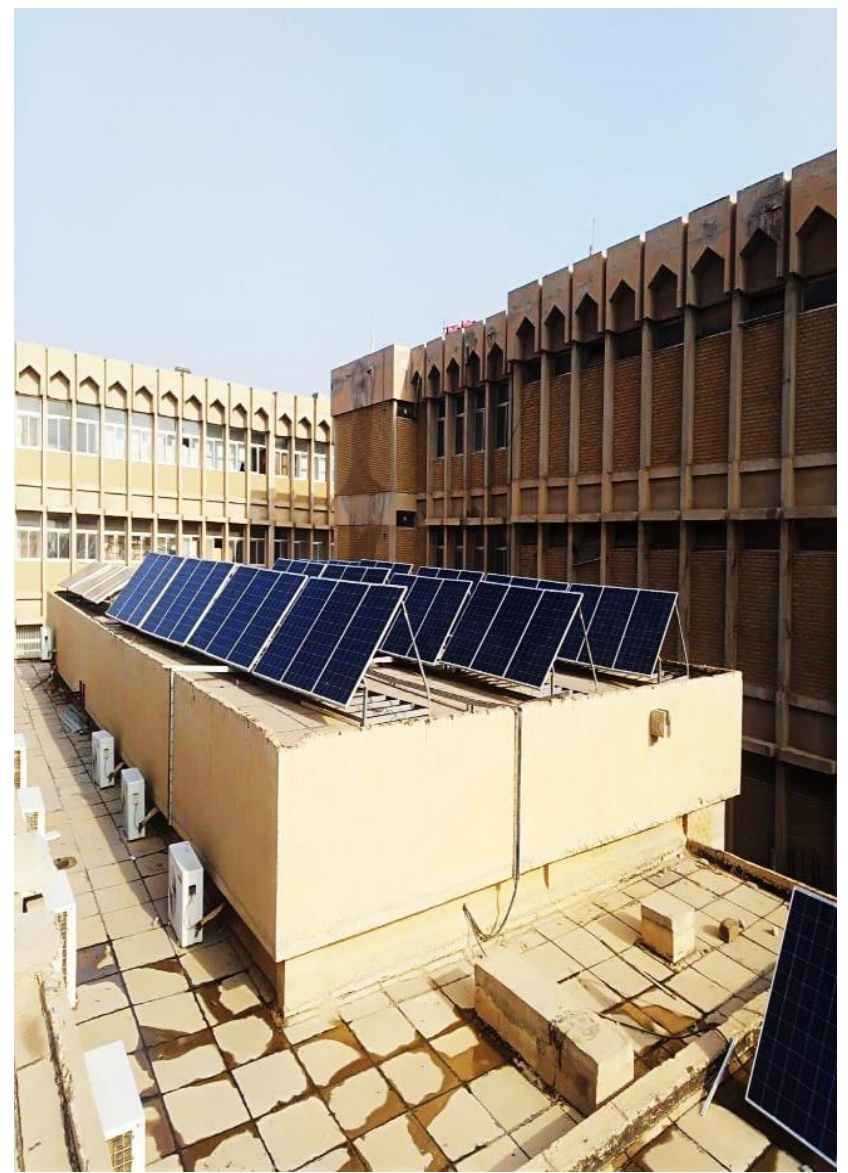

Fig.4 PV system Panels of Electrical Engineering Department laboratories - University of Basrah

\section{Results and Discussion}

\subsection{First Case Study of Hybrid system}

The climate data used in this result is from (Iraqi Meteorological Organization and Seismology, unpublished data 2017, Basrah Airport).

The data of solar power (Isc, Voc) that used in this result is for 2017 at Basrah/Iraq conditions as recorded at Dr.Jawad's home from inverter screen.

Fig. (5) shows the available solar power from 18 solar cells for the mentioned year.

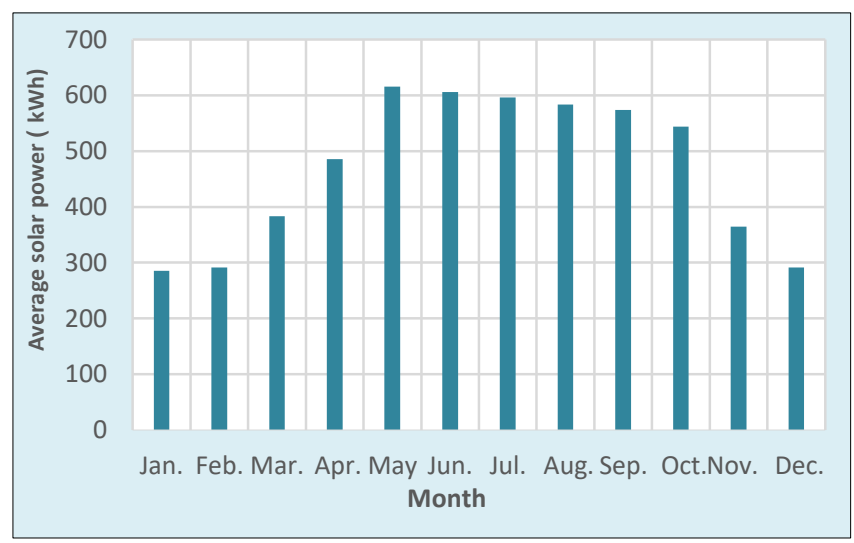

Fig.5 Available solar power at the home during 2017 
Theoretically, depending on wind information, we suggested using wind power to reduce annual energy consumption by using ( $4.5 \mathrm{~kW})$ wind power turbine (Rotor diameter $4.5 \mathrm{~m}$ ). Fig. (6) shows available wind power for 2017.

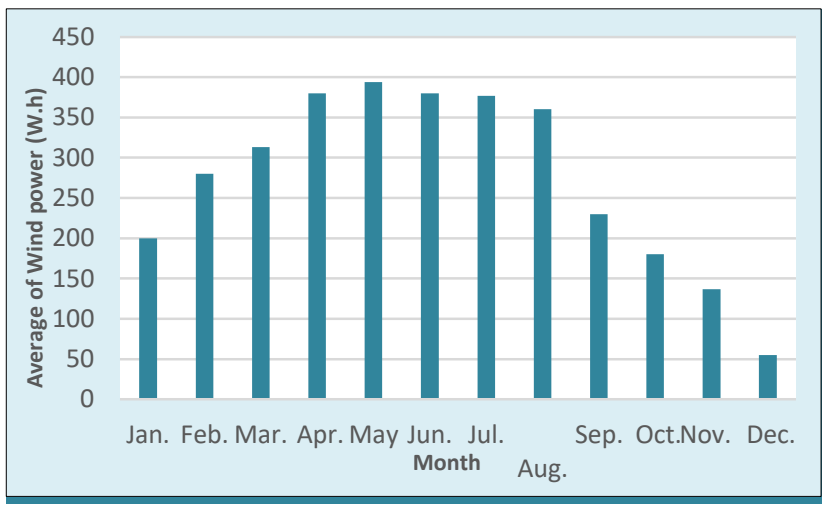

Fig.6 Available wind power at the home during 2017

Power consumption change with time. Two types of consumption were observed in the home; hot and cold months' consumption. Tables (2) and (3) show the loads details in the home during the cold and hot month respectively. The total annual power consumption is 33.24 MWh.See Fig. (7) and Table (4).

Table 2 Electric home load details for summer months

\begin{tabular}{|c|c|c|c|}
\hline Appliances & $\begin{array}{c}\text { Power } \\
\text { (W) }\end{array}$ & $\begin{array}{c}\text { Operation } \\
\text { period } \\
\text { (hour per } \\
\text { day) }\end{array}$ & $\begin{array}{c}\text { Total } \\
\text { power } \\
\text { (kW.h) }\end{array}$ \\
\hline Total indoor lights & 160 & 6 & 0.96 \\
\hline Total outdoor lights & 120 & 5 & 0.6 \\
\hline AAC & 9250 & 10 & 92.5 \\
\hline Refrigerators & 430 & 24 & 10.32 \\
\hline Water pump & 100 & 2 & 0.2 \\
\hline Washing machine & 500 & 1 & 0.5 \\
\hline Electric Water heater & 2400 & 1 & 2.4 \\
\hline Ceiling fans & 320 & 24 & 7.7 \\
\hline Total power consumed & & & $115.18 \mathrm{~K}$ \\
per day & & & Wh \\
\hline
\end{tabular}

Table 3 Electric home load details for winter months

\begin{tabular}{|c|c|c|c|}
\hline Appliances & $\begin{array}{c}\text { Power } \\
\text { (W) }\end{array}$ & $\begin{array}{c}\text { Operation } \\
\text { period } \\
\text { (hour per } \\
\text { day) }\end{array}$ & $\begin{array}{c}\text { Total } \\
\text { power } \\
\text { (kW.h) }\end{array}$ \\
\hline Total indoor lights & 160 & 7 & 1.12 \\
\hline Total outdoor lights & 120 & 6 & 0.72 \\
\hline Heater & 3000 & 10 & 30 \\
\hline Refrigerators & 430 & 24 & 10.32 \\
\hline Water pump & 100 & 2 & 0.2 \\
\hline Washing machine & 500 & 1 & 0.5 \\
\hline Electric Water heater & 2400 & 2 & 4.8 \\
\hline Total indoor lights & 160 & 7 & 1.12 \\
\hline Total power consumed & & & 46.66 \\
per day & & & $\mathrm{kWh}$ \\
\hline
\end{tabular}

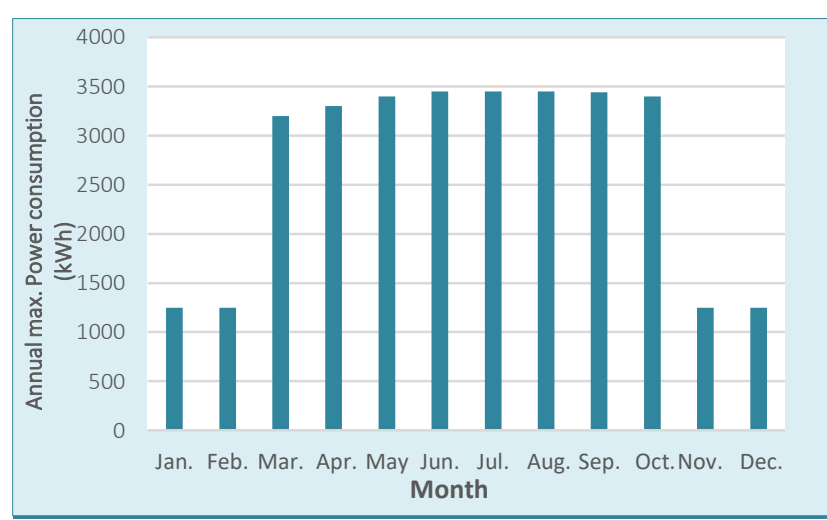

Fig.7 Total annual power consumption

Table 4 Schedule of total annual power consumption

\begin{tabular}{|c|c|}
\hline Month & Max. power consumption kW.h \\
\hline Jan. & 1400 \\
\hline Feb. & 1400 \\
\hline Mar. & 3400 \\
\hline Apr. & 3450 \\
\hline May & 3455 \\
\hline Jun. & 3455 \\
\hline Jul. & 3455 \\
\hline Aug. & 3455 \\
\hline Sep. & 3455 \\
\hline Oct. & 3400 \\
\hline Nov. & 1400 \\
\hline Dec. & 1400 \\
\hline
\end{tabular}

When using the PV panels as power sources to supply electrical power to operate the loads that scheduled, the solar power would be cover (5.7 MWh) about 17\% of total annual demand. Which made the total remaining required power reduced to (27.54 MWh). See Fig. (8).

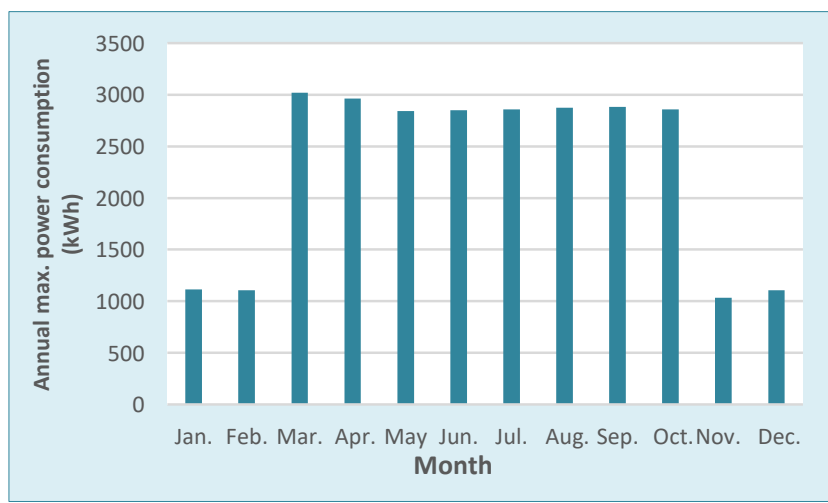

Fig.8 Total annual power consumption after using solar power

Getting benefits of batteries power also reduced the power consumption to about $7.5 \%$ when covering about (2.5 MWh) of total consumption and the remaining total load reduced to (25 $\mathrm{MWh}$ ) as in Fig. (9).

Also, the wind power could provide about a $6.8 \%$ (2.3MWh) reduction in annual power consumption by optimum charge/discharge scheduling Fig. (10). 
This makes the total power saving when using hybrid system resources about $31.3 \%$ by providing 10.4 MWh/year according to the mentioned year conditions.

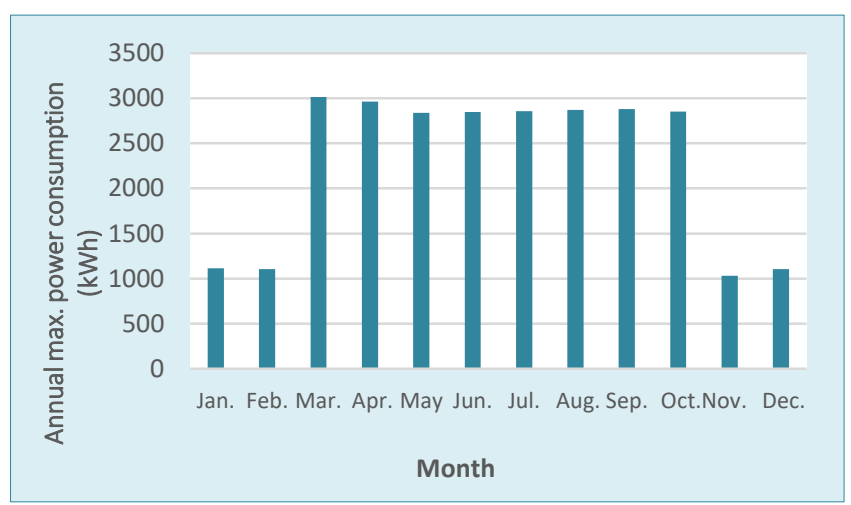

Fig.9 Total annual power consumption after using solar power and battery

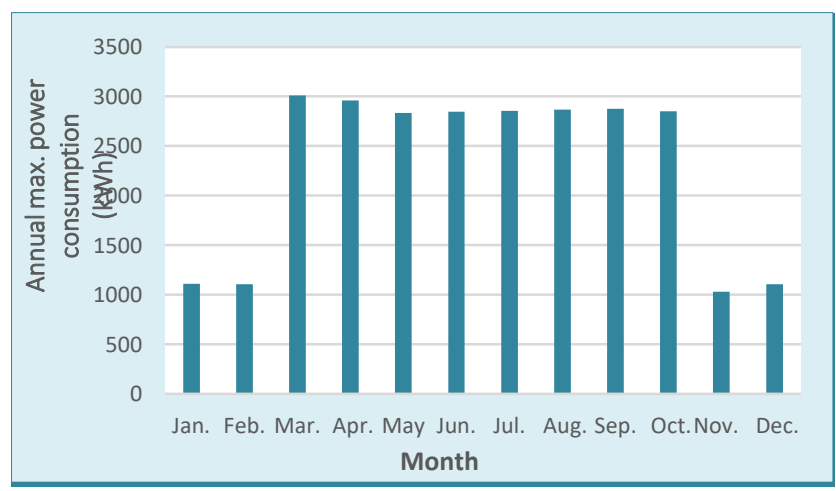

Fig.10 Total annual power consumption after using solar, battery and wind power

\subsection{Second Case Study}

For the purpose of proving that the hybrid system (solar panels-battery) successful in large areas, the six laboratories in the Department of Electrical Engineering -University of Basrah) will be studied. The hybrid system used consists of 40 solar cells and 8 batteries with a capacity of $10 \mathrm{~kW}$.

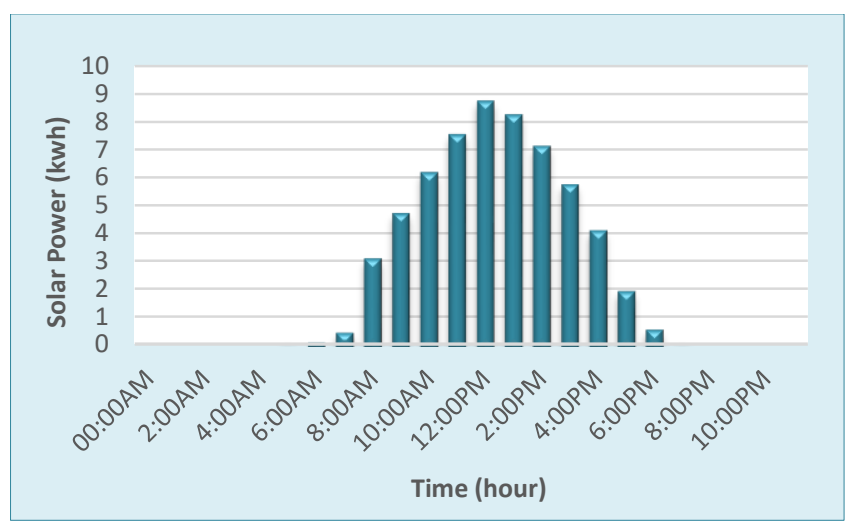

Fig.11 Available solar power in 25/5/2018
Fig. (11) which represents available solar power in 25/5/2018 as hot (perfect) day in the department.

The total daily power consumption in the all laboratories according to the daily schedule referred to in Table (4) is $1045.68 \mathrm{kWh}$ as shown in Fig. (12) which represented the total power consumption at 25/5/2018 for each hour of the day starts from 8:00 AM to 2:00 PM.

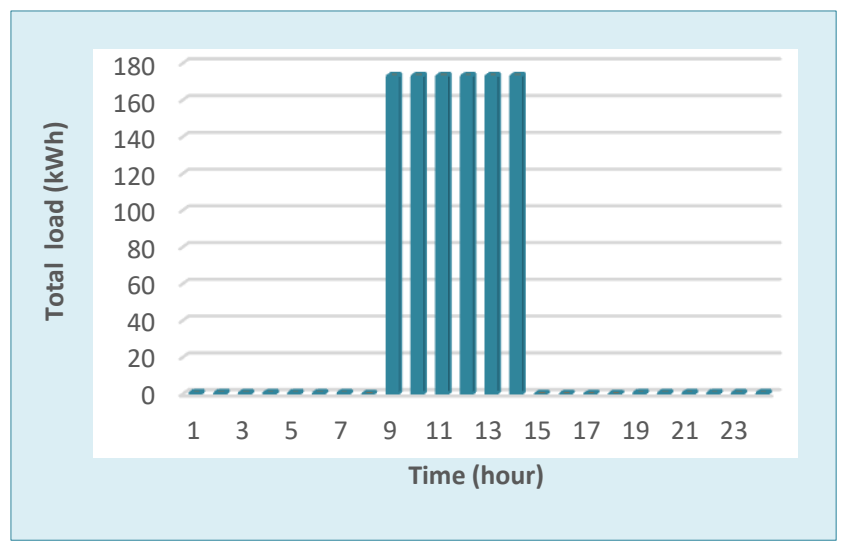

Fig.12 Total daily load of laboratories at hot day for electric Engineering Department

Table 4 Electric load details for all laboratories in the Department of Electrical Engineering at the University of Basrah

\begin{tabular}{|c|c|c|c|}
\hline Appliances & $\begin{array}{c}\text { Power } \\
(\mathrm{W})\end{array}$ & $\begin{array}{c}\text { Operation } \\
\text { period } \\
\text { (hour per } \\
\text { day) }\end{array}$ & $\begin{array}{c}\text { Total } \\
\text { power } \\
\text { (kW.h) }\end{array}$ \\
\hline Total indoor lights & 40 & 6 & 7.68 \\
\hline Total outdoor lights & 40 & 12 & 6.24 \\
\hline AC & 7000 & 6 & 1008 \\
\hline Ceiling fan & 100 & 6 & 5.4 \\
\hline Computer & 130 & 6 & 9.36 \\
\hline Other devices & 1500 & 6 & 9 \\
\hline Total indoor lights & 40 & 6 & 7.68 \\
\hline Total outdoor lights & 40 & 12 & 6.24 \\
\hline $\begin{array}{c}\text { Total power consumed } \\
\text { per day }\end{array}$ & & & $1045.68 \mathrm{k}$ \\
Wh
\end{tabular}

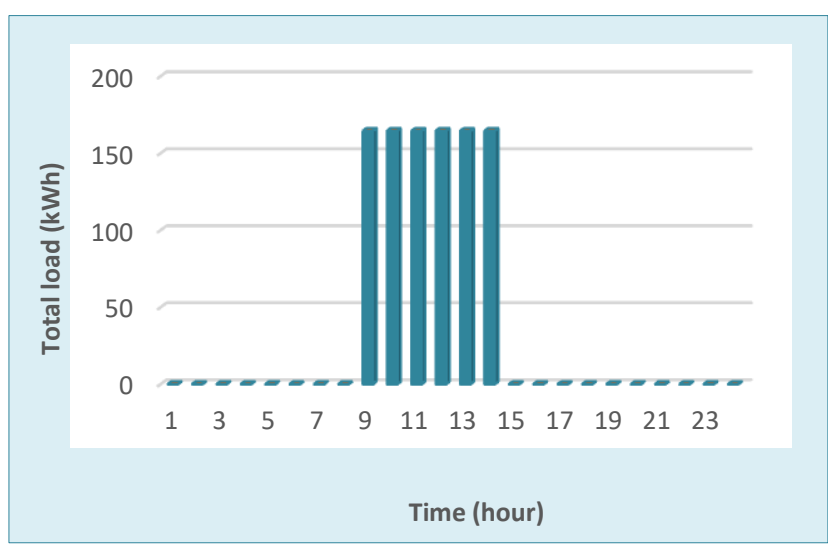

Fig.13 Total daily load after using PV, batteries 
When using the (PV panels - battery) to supply the loads that scheduled, the hybrid system would be cover (50 kWh) about $4.78 \%$ daily of total demand. See Fig (13)

This means that the load in all laboratories (32 total indoor light, 13 total outdoor light, 9 ceiling fans, one air conditioner device and other devices) running by hybrid system.

The remaining power can be transferred to the student's classes in the top floor.

\section{Conclusions}

According to the results from the two case studies, the following conclusions about the renewable energies in Basra city can be summarized:

1) Basra receives high solar energy intensity during the year. The average solar energy produced by the use of (18 solar panels only) between (200-650 Kwh) monthly.

2) According to the theoretical study, the Wind energy is available in Basrah city along the year.

3) When using the PV panels as power sources to supply electrical power to operate the loads the solar power would be cover (5.7 MWh) about $17 \%$ of total annual demand, which is about(33.24MWh), Which made the total remaining required power reduced to $(27.54$ MWh.

4) The batteries power reduced the power consumption to about $7.5 \%$ when covering about (2.5 MWh) of total consumption.

5) The wind power could provide about a $6.8 \%$ (2.3MWh) reduction in annual power consumption by optimum charge/discharge scheduling.

6) The total power saving when using hybrid system resources in the house about $31.3 \%$ by providing $10.4 \mathrm{MWh} /$ year according to the mentioned date conditions.

7) Through the study of the laboratories of the Department of Electrical Engineering at the University of Basrah, it is observed that it is possible to operate many electrical appliances at the same time depending on the hybrid system such as fans, lighting, and computers and it is noted that the air conditioners can be operated by using more and more solar cells and batteries.

\section{References}

Ekren O, Ekren BY, Ozerdem B. Break-even analysis and size optimization of a PV/wind hybrid energy conversion system with battery storage - a case study. Applied Energy 2009;86(7-8):1043-54.

Onar OC, Uzunoglu M, Alam MS. Modeling, control and simulation of an autonomous wind turbine/photovoltaic/fuel cell/ultra-capacitor hybrid power system. Journal of Power Sources 2008;185(2):1273-83.

Reichling JP, Kulacki FA. Utility scale hybrid wind-solar thermal electrical generation: a case study for Minnesota. Energy 2008; 33:626.

Yang H, Zhou W, Lu L, Fang Z. Optimal sizing method for stand-alone hybrid solar-wind system with LPSP technology by using genetic algorithm. Solar Energy 2008; 82:354.

Liu Li-qun, Wang Zhi-xin. The development and application practice of wind- solar energy hybrid generation systems in China. Renew Sustain Energy Rev 2009; 13:1504-12.

S. Dihrab. And K. Sopian., Electricity generation of hybrid PV/wind systems in Iraq", Renewable Energy 35, 13031307, (2010).

A. Ismael.," Off-Grid Electricity Generation with Hybrid Renewable Energy Technologies In Iraq: An Application of Homer", ISSN 1999-8716, (2015).

Abd al-Raheem, A. T., Simulation of different electricity generation systems to be used in Marshes and far areas" M. Sc. Thesis, University of Basrah, 2017.

C. McGregor., Design for a wind farm in the Town of Auburn, MA", A Major Qualifying Project Report submitted to the faculty of the Worcester Polytechnic Institute in partial fulfillment of the requirements for the Degree of Bachelor of Science, (2010).

Ai, B., Yang, H., Shen, H., Liao, X. Computer-aided design of PV/wind hybrid system Renewable Energy 28-14911512, 2003.

https://ar.Wikipedia. Org./wiki/ 2014.

https://www.google.com/earth/ 2013.

Iraqi Meteorological Organization and Seismology, unpublished data 2017, Basrah Airport. 